\title{
Effects of Wheat and Fish Trade Restriction Policies on Households' Vulnerability to Poverty in Nigeria
}

\author{
Yusuf A. Wasiu Ph.D. \\ Department of Economics, Nile University of Nigeria, FCT Abuja \\ Yusuf A. Sulaiman Professor \\ Department of Agricultural Economics, University of Ibadan, Nigeria \\ Oni, A. Omobowale Professor \\ Department of Agricultural Economics, University of Ibadan, Nigeria \\ Adepoju, O. Abimbola Ph.D. \\ Department of Agricultural Economics, University of Ibadan, Nigeria \\ JEL Classification: Q
}

\begin{abstract}
Against the expected trade liberalization policies as enunciated under the World Trade Organization (WTO) agreement, Nigeria currently uses trade restriction policies through tariffs and quotas to protect local producers and ensure self-sufficiency in staple food especially wheat and fish, which constitute $56 \%$ of annual food import. However, the general equilibrium effects of restrictive policy instruments are yet to be fully understood especially for the poor and the vulnerable. Living Standard (HNLSS) survey data for 2009/2010 and the NISER's 2011 Social Accounting Matrix (SAM) were used. An 80\% wheat and 50\% fish tariff increase as currently implemented in Nigeria were used for the simulations. Data were analyzed using computable general equilibrium (CGE) technique and Vulnerability To Poverty (VTP) measure. Prior to policy simulations, vulnerable rural and urban households in NW had the highest observed poverty $(68.2 \%$ and $71.2 \%)$ while, while the rural and urban households in the south-south zone had the least $(53.0 \%$ and $45.5 \%)$ respectively. The expected poverty was highest in simulation three across vulnerable and non-vulnerable households. Consequently, the ratio of expected to observed poverty indicates that vulnerable rural and urban households have the highest likelihood of sinking deeper into poverty particularly with the combined policies in simulation three. It is therefore recommended that government should strengthen domestic production of food import substitutes backed with strong value addition.

Keywords:Computable general equilibrium, Per-capita consumption expenditure, Social accounting matrix, Trade restrictions, Vulnerability to poverty

DOI: $10.7176 / \mathrm{JPID} / 50-06$

Publication date: June $30^{\text {th }} 2019$

\section{Introduction}

Most developing countries are known to require increasing quantities of certain imports which they cannot produce efficiently. This is particularly the case for capital goods, some intermediate goods and most raw materials. Imports are essential parts of international trade and import of capital goods is important to economic growth. Imported capital goods directly affect investment, which constitutes the engine of economic growth. Recently, in Nigeria the value of food import has grown to such an extent that no sane government will like to fold its arms. Nigeria agriculture is not growing, people have develop a good taste for imported foods, food import bill has grown to over one trillion naira for only four food items (wheat, rice, fish and sugar), agricultural production have been characterized with various shades of disincentives, and the worst of it all, is the falling price of crude oil at the international market. Crude oil revenue alone accounts for over 70 percent of government revenue and about 90 percent of non-oil income. These factors alone have created the need for an urgent shift from been an import dependent and consuming nation to one of an active food producing economy. This is because we can leverage on our vast agricultural land and water resources and an abundant human resources. The major marketing strength of Nigeria is the large population of people that can consume the produce. Thus, the only requirement for closing the gap between food demand and supply is the creation of enabling environment for value addition in major commodities that can substitute for imports. This is the cardinal aim of the agricultural transformation agenda such that Nigeria government can over time save the huge amount being spent annually on food import.
\end{abstract}




\section{Wheat Transformation Agenda and its Prospects}

Nigeria currently produces about 300,000 tons of wheat annually, which is less than $10 \%$ of the 4 million tons imported into the country each year. The federal government wishes to revive domestic wheat production as part of her ATA. The target of the wheat Transformation Agenda (WTA) is to increase the domestic production of wheat from 300,000 ton to 1.5 million tons per annum by 2017 . The WTA is expected to generate about 1 million jobs especially in the rural areas over the next 4 years and also generate over N42 billion incomes annually for farmers and millers (FMARD, 2014). The prospects for the actualization of the WTA and increased domestic production of wheat shall address the causes of previous failures. For instance, the issue of poor yield $(2 t / h a)$ have been addressed. The research work of 3 institutes namely International Maize and Wheat Improvement Centre (CIMMYT), International Centre for Agricultural Research in the Dry Areas (ICARDA) and Lake Chad Research Institute (LCRI) have developed and released two high yielding $(5-6 \mathrm{t} / \mathrm{ha})$ wheat varieties (FMARD, 2014). The FMARD have begun aggressive in the distribution of the improved seeds among farmers in Northern Nigeria. In the 2013/2014 dry season, 9143 farmers in 8 Northern Nigeria states (Kano, Jigawa, Kebbi, Zamfara, Borno, Yobe, Gombe and Sokoto) were freely given improved seeds. About 2500 ha of wheat field was cultivated in the 2013/2014 dry season. Similarly, it is projected that 75,000 hectares will be planted in the 2014/2015 season, 150,000 hectares in 2015/2016 and 300,000 hectares in 2016/2017 season. Then with an average yield of $5 \mathrm{t} / \mathrm{ha}$, Nigeria could produce 1.5 million tons by 2017 (FMARD, 2014). With this, Nigeria could achieve/attain $37.5 \%$ domestic production of its 4 million MT wheat demand. In addition, the $10-$ $20 \%$ cassava inclusion in bread that is ongoing, Nigeria could substitute $50 \%$ of its wheat imports. CIMMYT similarly supported the release of improved bread and durum wheat cultivars to farmers in Ethiopia (CIMMYT, 2000). As part of the cassava-wheat bread policy of 15 July 2012, Nigeria established the Cassava Bread Development Fund (CBDF), which was funded by levies from wheat importation $(20 \%$ of wheat grain and $100 \%$ for wheat flour) (Ohimain, 2014). Recent report shows that about N9.9 billion of Cassava Bread Development Fund (CBDF) is currently being managed by the Bank of Industry and Bank of Agriculture (Fadare, 2014). The Federal Government planned to support domestic wheat farmers and millers with the procurement of $500 \mathrm{~kg} / \mathrm{hr}$ milling equipment using the CBDF (FMARD, 2014)

Fish Production and Prospect in Nigeria Agricultural Transformation Agenda: Nigeria has an actual annual fish demand of 2.68 million, annual domestic production 0.78 million with a demand-supply gap of 1.8 million tons. Low annual consumption of $7.5 \mathrm{~kg}$ as against $15 \mathrm{~kg}$ recommended (Sustainable Aquaculture Digital News, 2014). The need for a strong domestic capture and aquaculture fisheries in Nigeria is supported by the fact that $70 \%$ of Nigerians and live in rural areas while $65 \%$ of the labour force is involved in the agricultural sector (Miller et al., 2007). The Federal Government's Special Growth Enhancement Support Scheme for Fisheries and Aquaculture Value Chain programme was set up to increase the production of fish through farming and aquaculture by 1 million tons over a period of four years through the Aquaculture Value Chain, AVC. The goal was to achieve the Agricultural Transformation Agenda (ATA) by which the Agricultural Value Chain would enable the environment to sustainably generate increased production in aquaculture industry. The Special Growth Enhancement Support Scheme was meant to add 1.25 billion tons of fingerlings, 400,000 tons of fish feed, 250,000 tons of table fish and 100,000 tons of value added fish products (Sustainable Aquaculture Digital News, 2014). The Federal Government of Nigeria also favoured a ban on fish imports. This implied that the Federal Government followed an import substitution policy to facilitate the growth of the Nigeria aquaculture industry.

Many developing countries rely heavily on import controls for achieving adjustment in the balance of payments. However, most of their empirical analyses on imports do not consider explicitly quantitative restrictions. The following are some of the empirical studies conducted on import demand in developing countries. Minor and Mureverwi (2013) employed a CGE model which disaggregates the regional household into separate private, government and investment entities. The private household was further disaggregated into ten income quintiles for both rural and urban populations based on recent household survey data. Linkages between household incomes and the prices of consumption were specified to determine the impacts of the proposed trade agreements on Mozambique's poorest households (the first three quintiles represent households below or near the poverty line). The separation of the government sector from households allowed for a detailed analysis of government balances, which were directly impacted by the gains and losses to tax revenues. The result of analysis revealed that the completion of the Regional Economic Cooperation had modest, but positive impacts on pro-poor growth in Mozambique.

Bhasin (2008) studied the impact of unilateral and partial agricultural trade liberalisation in isolation, combined with foreign capital inflows and value added tax on poverty of various categories of households in Ghana, using the CGE model, social accounting matrix and Ghana's living standards survey "4" data for 1999. The study revealed that the elimination of trade related import and export tariffs on agricultural goods in isolation, combined with foreign capital inflows and value added tax reduced the incidence, depth and severity of poverty of all categories of households. It also showed that financing of unilateral partial agricultural trade 
liberalisation through domestic resources (value-added tax) could have a greater impact on poverty alleviation than the foreign resources (foreign capital inflows).

Obi-Egbedi et al (2013) examined the welfare effects of rice trade policies on Nigeria households as it constantly swings between protectionist and liberalisation trade policies over the years. The study employed a static computable general equilibrium model to assess the effect of the protectionist policy of $80 \%$ tariff increase and the liberalisation policy of $5 \%$ tariff reduction on production sectors, macroeconomic aggregates, and households' welfare in Nigeria. Simulation results reveal that output in the rice and other agriculture sectors increased, by about $1 \%$ more, under the liberalised policy than the protectionist policy. The manufacturing and services sector increased in labour, composite price and returns to capital by less than $1 \%$ while the same fell under the protectionist policy. Almost all macroeconomic aggregates fell under both policies but with a greater magnitude under the protectionist policy. Wage rate increased under the liberalised policy only, by less than $1 \%$. Although rural households' incomes increased under the protectionist policy, social welfare declined under both policies but was less with the $5 \%$ reduction in tariff. Hence this policy was recommended for adoption in order to increase growth of sectors and minimize welfare losses to households.

Nkang et al (2013) assessed the impact of food price shocks due to global economic crisis on agriculture and the poor in Nigeria. The study simulated the impact of a rise in the price of imported food on agriculture and household poverty in using a computable general equilibrium (CGE) model and the Foster, Greer and Thorbecke (FGT) class of decomposable poverty measures on the 2006 social accounting matrix (SAM) for Nigeria and the updated 2004 Nigeria Living Standards Survey (NLSS) data. Results show that a rise in import price of food increased domestic output of food but reduced the domestic supply of other agricultural commodities as well as food and other agricultural composites. Furthermore, a rise in the import price of food increased poverty nationally and among all household groups, with households in the rural north being the least affected by the shock, while their rural-south counterparts were the most affected. A major policy implication drawn from the study is that high import prices in import competing sectors like agriculture tend to favour the sector but exacerbate poverty in households. Thus, efforts geared at addressing the impact of this shock should strive to balance welfare and efficiency issues.

Yusuf (2002) study was designed to provide an understanding of the general equilibrium effects of liberalisation measures with respect to poverty situation of households, taking cognizance of the interrelationships between the agents and sectors of the economy. The study examined the effects of two liberalization measures on the poverty situation of four different household categories (rural agriculture, rural non-agriculture, urban low education and urban high education households). The findings reveal that poverty is most pronounced in rural agricultural households, followed by urban low education households. The informal sector of the economy provides employment for the majority of rural non agricultural and urban low-education households. The simulation on the base year equilibrium shows that liberalization has varying effects on the poverty of households. A reduction in the export prices of agricultural commodities leads to an aggravated poverty among rural agricultural households while a reduction in import tariffs led to reduced poverty with some level of unemployment. The study therefore recommends a re-examination of both the horizontal and the vertical agricultural diversification.

\section{Features of the Model and Methodology}

This study adopted a PEP Standard Single Country Comparative Static Computable General Equilibrium (CGE) model designed for the study of an open-economy that treats the rest of the world (excluding Nigeria) as one trading agent (Decaluwe, et al (2013); and was calibrated using 2011 Nigeria SAM by Nigeria Institute for Social and Economic Research (NISER). The model employs the standard assumptions, that producers maximize profits subject to production functions, households maximize utility subject to budget constraints, factors are mobile across activities; are available in fixed supplies; and are demanded by producers at market clearing prices. The model also satisfies Leon Walras' law which states that the set of commodity market equilibrium conditions are functionally dependent, and it is homogeneous of degree zero in prices. The model comprised of six sectors (wheat, fish, other agriculture, manufacturing, crude oil and mining, and services); two factors of production (labour and capital); and twelve household categories (rural and urban households in each of the north central, north east, north west, south east, south-south and southwest zones).

The study adopted a computable general equilibrium model to generate the economy-wide (macro) impact of import tariffs restriction for wheat and fish respectively on households' vulnerability to poverty. The Computable General equilibrium model based on national accounting data was preferred due to the fact that macroeconomic shocks to any of the sectors do easily filter through the economy and are characterised by strong general equilibrium effects. Also, households' vulnerability to poverty was analysed on account that it can capture households that are vulnerable even though they have been hitherto recognised as either poor or non poor without paying attention to their vulnerability status. Based on that, the study merged the two approaches such that a macro-micro modeling framework which specifically integrated twelve household categories into a CGE 
model was achieved. This is a case of a representative household model approach in general equilibrium analysis of distributional implications of macroeconomic shocks and policies (Cockburn, 2001; Bhasin, 2008; Nkang, 2013).

The study then carried out the execution of the approach in a stepwise manner. The first step involved the building of a CGE model, based on the 2011 Social Accounting Matrix (SAM) containing twelve representative households from the Harmonized Nigeria Living Standard Survey data (HNLSS). This gave rise to the baseline equilibrium solution used to carry out the counterfactual experiments such that the impact of wheat and fish tariffs could be observed for the study. The counterfactual experiments then gave rise to different shades of variations in the household average expenditures, labour demand, capital demand, government revenues and government expenditures among others. The next step involved the plugging of the average household's expenditure into the equation of 'Vulnerability as Expected Poverty' (VEP), an ex-ante measure proposed by Chaudhuri et al. (2002) which was adopted because of its ability to identify households exposed to risks but who are not poor. The vulnerability of households during the current period, $\mathrm{V}_{\mathrm{t}}$, is dependent on the probability that future household consumption $\hat{c}$ will be less than poverty line $\mathrm{c}$.

Empirically, by building upon the works of Chaudhuri et al. (2002) and Gaiha et al. (2004), VEP was obtained by the following procedure: Firstly, the mean per capita consumption expenditure and the respective standard deviation for each of the twelve (12) households categories was obtained from the summary statistics of the HNLSS 2009 data. This is combined with the relative poverty line of N66,204.00 using the formula:

$$
V_{i j}=P\left(\ln c_{i j}<\ln \bar{c} / X, Z\right)=\phi\left(\frac{\ln \bar{c}-\ln \hat{c}}{\sqrt{\sigma_{i j}^{2}}}\right)
$$

where

$\phi()=$. the cumulative density of the standard normal distribution function;

$-$

$C_{=}$poverty line (relative poverty line)

$\ln \hat{c}_{i j}=$ expected mean of per capita log consumption

$V_{i j}=$ the estimated vulnerability or probability to fall below the poverty line.

This gave rise to households' vulnerability status at the baseline, and thereafter, that of the counterfactual policy experiments tested.

Secondly, the probability of expected poverty (vulnerability) estimates obtained for the base line and the after-shocks CGE simulation results were then compared to see the effects of policy change on the households. A vulnerability to poverty threshold level of 0.5 was employed, since it is widely accepted as a reasonable threshold (Pritchett et al, 2000; Chaudhuri et al, 2002; Zhang et al, 2008; Oni et al (2008); and Adepoju et al (2011)). The following reasons justify the choice of the vulnerability threshold of 0.5 . First, it makes intuitive sense to say that a household with a $50 \%$ probability of falling into poverty in the next period is vulnerable to poverty. Second, when a household whose current level of consumption is equal to the poverty line faces a zero mean shock; it has a one period ahead vulnerability of 0.5 . In the limit, as the time horizon approaches zero then being currently poor and being vulnerable to poverty coincides (Pritchett et al, 2000). Also Zhang et al (2008) found that a vulnerability line of 0.5 provides a more improved prediction. This implies that households with estimated vulnerability to poverty above or equal to 0.5 are considered to be vulnerable to poverty. This study also supports argument of Novignon et al, (2012) that the certainty of the probability that a household or an individual will become poor exactly one period ahead is impractical and hence the time horizon should be any period in the future. The time horizon was therefore specified in this study as $t+j$ instead of $t+1$, where $j \geq 1$ (Chaudhuri et al, 2002; Christiaensen et al, 2005, Novignon et al 2012).

Therefore, households' categories with expected poverty indices below the vulnerability to poverty threshold (0.5) were regarded as non-vulnerable while those equal to or above the vulnerability threshold were classified as vulnerable. Finally, the estimation of the ratio of the expected poverty to observe poverty was estimated to obtain the probability ratio of households expected poverty (the same process was repeated for each simulated scenario).

\section{The Results: (from Policy Simulations)}

In this section, we report the simulation results of the impacts of $80 \%$ and $50 \%$ tariff increase for wheat and fish, respectively. We report the impacts of such policy shock on macroeconomics and sectoral indicators, returns to labour and capital investment, and households' consumption budgets. We then use the outcome of the 
consumption expenditure budgets to determine whether the households have been made more vulnerable, less vulnerable, or unchanged.

\section{Macroeconomic and Sectoral Impacts of Import Tariff}

Table 1 summarizes the macroeconomic impacts of the policy shocks. It reveals the percentage change increase in GDP was observed in all the scenarios. The highest percentage increase in GDP was recorded in simulation where combined restrictions of wheat and fish importation were experimented. Government revenue from import duties increased tremendously throughout the scenarios with the highest increase in the combined simulation. Percentage change in government savings also increased and the highest savings was recorded in the combined simulation for wheat and fish restriction. The percentage change in aggregate import for all cases reduced. Conversely, the general price level increased in all cases of import restrictions experimented. It is hoped that this would give local producers of such commodities the opportunity to earn remunerative prices from the sale of their commodities. All these outcomes are in line with the expectations of both classical and the neo-classical macroeconomic principles (Torrens, 1844; Chipman 1987). Table 2 reveals the consumption of wheat and fish for investment purposes by other sectors. All the sectors in the model experience increases in their investment in all cases of import tariff restrictions tested. Although the growth in investment, which is slightly less than 3\%, is the highest, but it cut across all the sectors for the combined protection of wheat and fish scenario. The growth in investments experienced due to import restrictions of the two commodities could be queried by pro-trade liberalization experts because liberalization of trade facilitate competition, but in a country like Nigeria where agricultural sector alone employs about 60 to 70 percent of the populace, where the vast majority of the actors are rural based and largely non-competitive. Such sector should be protected while the value addition and export promotion policies that can promote competitiveness are being implemented.

Table 1: Macroeconomic Impacts of Import Tariff (\% change from baseline)

\begin{tabular}{|l|r|r|r|r|r|r|r|}
\hline & RGDP & Govt. Rev & $\begin{array}{l}\text { Govt. } \\
\text { Savings }\end{array}$ & $\begin{array}{l}\text { Gov. } \\
\text { Inv. } \\
\text { Exp. }\end{array}$ & $\begin{array}{l}\text { Aggregate } \\
\text { Import }\end{array}$ & $\begin{array}{l}\text { Cons. Price } \\
\text { Index }\end{array}$ & $\begin{array}{l}\text { Total Gov. } \\
\text { Income }\end{array}$ \\
\hline $\begin{array}{l}\text { An 80\% increase in } \\
\text { wheat tariff }\end{array}$ & 0.102 & 71.147 & 0.793 & 1.713 & -4.918 & 0.161 & 0.263 \\
\hline $\begin{array}{l}\text { A 50\% increase in fish } \\
\text { tariff }\end{array}$ & 0.086 & 42.976 & 0.379 & 0.930 & -4.683 & 0.101 & 0.126 \\
\hline $\begin{array}{l}80 \% \text { wheat \& 50\% fish } \\
\text { tariff increase }\end{array}$ & 0.201 & 114.256 & 1.171 & 2.643 & -9.520 & 0.262 & 0.390 \\
\hline
\end{tabular}

Source: Computed from GAMS result 2015

Table 2: Impact of Tariff Restriction on Sectoral Gross Fixed Capital Formation (\% change from baseline)

\begin{tabular}{|l|r|r|r|r|r|}
\hline & $\begin{array}{l}\text { Other } \\
\text { Agricultural } \\
\text { produce }\end{array}$ & Manufacturing & $\begin{array}{l}\text { Crude and } \\
\text { Mining }\end{array}$ & Services & Trade \\
\hline $80 \%$ tariff increase in wheat & 1.656 & 1.684 & 1.687 & 1.660 & 1.640 \\
\hline $50 \%$ tariff increase in fish & 0.863 & 0.895 & 0.900 & 0.867 & 0.845 \\
\hline $\begin{array}{l}80 \% \text { wheat \& 50\% fish tariff } \\
\text { increase }\end{array}$ & 2.519 & 2.580 & 2.587 & 2.526 & 2.484 \\
\hline
\end{tabular}

Source: Computed from GAMS result 2015

\section{Impact of Tariff Restriction on Returns to Labour and Capital}

The impact of various trade policy reforms on the demand for labour and capital were also examined (Tables 3 ). The percentage change in demand for labour and capital increased due to import restriction to trade in wheat and fish. An average of about $13 \%$ increase was observed for wheat while fish sector recorded an average of about $2 \%$. The high demand for labour and capital recorded for wheat import restriction scenarios may be due to the fact that imported wheat is believed to be of better quality and is priced higher than the locally produced substitute. However, once supply of imported wheat is constrained by tariff imposition, the price of the local substitute follows the trend of the imported wheat and the producers are then encouraged to grow more, thus creating a competitive demand for labour and capital. Also, wheat is favoured in trade restriction scenarios due to the lack of close substitutes for industrial use. Even though, of recent, High Quality Cassava Flour (HQCF) was introduced by the International Institute of Tropical Agriculture (IITA), its inclusion in wheat flour-based products is yet to attract nationwide acceptance. Unlike wheat, fish has close substitutes such as poultry meat, mutton, chevon and beef, in which case, a rise in price of fish due to trade restrictions, may force the households to shift their demand to other animal protein sources, which accounts for why the increase in returns to labour 
and capital for fish could not match that of wheat. The manufacturing sector also recorded a slight percentage increase in demand for labour and capital in scenarios of wheat import restrictions, possibly due to increased demand for domestically produced products. The trade sector too experienced a rise during trade restrictions due to the favourable balance it enjoyed as a result of trade protection. Other sectors, except trade experience a slight reduction in demand for labour and capital in all cases of restriction though it is expected for other agricultural produce and services sectors because resources would be reallocated to wheat and fish sectors that are in high demand for labour and capital. Unexpectedly, the same was observed for the crude oil and mining sectors. However, it would be very difficult to rule out the possibility of beneficial multiplier effects of growth in demand for labour and capital for productive activities not to trickle down to other sectors, especially in Nigeria where productive activities are mostly powered by generating plants due to erratic supply of electricity.

Table 3:Impact of Tariff Restriction on Returns to Labour and Capital (\% change from baseline)

\begin{tabular}{|l|r|r|r|r|r|r|r|}
\hline & Wheat & Fish & $\begin{array}{l}\text { Other } \\
\text { Agriculture }\end{array}$ & Manufacturing & $\begin{array}{l}\text { Crude } \\
\text { and } \\
\text { Mining }\end{array}$ & Services & Trade \\
\hline $80 \%$ tariff increase in wheat & 12.852 & 0.115 & -0.082 & 0.046 & -0.153 & -0.009 & 0.155 \\
\hline $50 \%$ tariff increase in fish & -0.166 & 1.641 & -0.056 & -0.035 & -0.184 & -0.043 & 0.074 \\
\hline $\begin{array}{l}80 \% \text { wheat \& 50\% fish tariff } \\
\text { increase }\end{array}$ & 12.665 & 1.525 & -0.138 & 0.011 & -0.336 & -0.050 & 0.228 \\
\hline
\end{tabular}

Source: Computed from GAMS result 2015

Table 4:Impact of Tariff Restriction of Wheat and Fish on Households' Consumption Budget (\% change from baseline)

\begin{tabular}{|c|c|c|c|c|c|c|}
\hline & N-Central & N-East & N-West & S-East & S-South & S-West \\
\hline \multicolumn{7}{|c|}{ Vulnerable Rural Households } \\
\hline $\begin{array}{l}\text { SIM.1: } 80 \% \text { increase in wheat } \\
\text { tariff }\end{array}$ & 0.081 & 0.080 & 0.074 & 0.074 & 0.073 & 0.076 \\
\hline SIM.2: $50 \%$ increase in fish tariff & 0.055 & 0.054 & 0.050 & 0.050 & 0.050 & 0.051 \\
\hline $\begin{array}{l}\text { SIM.3: } 80 \% \text { \& } 50 \% \text { increase in } \\
\text { wheat \& fish tariff }\end{array}$ & 0.130 & 0.138 & 0.145 & 0.135 & 0.134 & 0.139 \\
\hline \multicolumn{7}{|c|}{ Non-Vulnerable Rural Households } \\
\hline $\begin{array}{l}\text { SIM.1: } 80 \% \text { increase in wheat } \\
\text { tariff }\end{array}$ & 0.076 & 0.081 & 0.079 & 0.084 & 0.082 & 0.087 \\
\hline SIM.2: $50 \%$ increase in fish tariff & 0.052 & 0.055 & 0.054 & 0.057 & 0.056 & 0.059 \\
\hline $\begin{array}{l}\text { SIM.3: } 80 \% \text { \& } 50 \% \text { increase in } \\
\text { wheat \& fish tariff }\end{array}$ & 0.142 & 0.152 & 0.146 & 0.153 & 0.152 & 0.161 \\
\hline \multicolumn{7}{|c|}{ Vulnerable Urban Households } \\
\hline $\begin{array}{l}\text { SIM.1: } 80 \% \text { increase in wheat } \\
\text { tariff }\end{array}$ & 0.073 & 0.072 & 0.066 & 0.066 & 0.065 & 0.068 \\
\hline SIM.2: $50 \%$ increase in fish tariff & 0.046 & 0.046 & 0.042 & 0.042 & 0.042 & 0.043 \\
\hline $\begin{array}{l}\text { SIM.3: } 80 \% \text { \& } 50 \% \text { increase in } \\
\text { wheat \& fish tariff }\end{array}$ & 0.110 & 0.109 & 0.108 & 0.118 & 0.102 & 0.128 \\
\hline \multicolumn{7}{|c|}{ Non-Vulnerable Urban Households } \\
\hline $\begin{array}{l}\text { SIM.1: } 80 \% \text { increase in wheat } \\
\text { tariff }\end{array}$ & 0.068 & 0.073 & 0.070 & 0.075 & 0.074 & 0.078 \\
\hline SIM.2: $50 \%$ increase in fish tariff & 0.043 & 0.046 & 0.045 & 0.048 & 0.047 & 0.049 \\
\hline $\begin{array}{l}\text { SIM.3: } 80 \% \text { \& } 50 \% \text { increase in } \\
\text { wheat \& fish tariff }\end{array}$ & 0.108 & 0.109 & 0.108 & 0.109 & 0.110 & 0.120 \\
\hline
\end{tabular}

Source: Computed from GAMS result 2015

Impacts of Tariff Restriction of Wheat and Fish on Households' Disposable Income

Table 4 presents information on the impacts of the three simulation scenarios on households' disposable income. All households across rural and urban experienced positive increase in their disposable income, the highest increases across households were in simulation 3 where wheat and fish tariff reduction was experimented. However, rural households have greater percentage increase in disposable income than their urban counterparts. This addition to households' disposable income, according to this study, was justified, considering the fact that households have enjoyed increased income as a result of increased demand for labour and capital and the 
sectoral gross fixed capital formation.

\section{Impact of Tariff Restriction of Wheat and Fish on Households' Expected Poverty}

Table 5 shows the expected poverty (after shock simulations) for all households' categories across the six geopolitical zones alongside the observed poverty. Expected poverty was highest for simulation 3 across households when compared with expected poverty obtained for simulations 1 and 2 where 80 percent wheat and 50 percent fish tariff increase were separately experimented. This clearly points to higher households' predicted poverty when compared with the baseline poverty and it simply mean that the vulnerable households will be worse than they presently were in future. Although, all households had enjoyed positive increase in their disposable income (as a result of increased demands for labour and capital) but the increase in consumption expenditure too was high enough to overshadow the increase in disposable income and this was the reason why more households were worse off than before.

Table 5: Impact of Tariff Restriction of Wheat and Fish on Households Expected poverty

\begin{tabular}{|c|c|c|c|c|c|c|}
\hline & N-Central & N-East & N-West & S-East & S-South & S-West \\
\hline \multicolumn{7}{|c|}{ Vulnerable Rural Households } \\
\hline Observed Poverty & 53.5 & 66.4 & 68.2 & 57.2 & 53.0 & 54.7 \\
\hline SIM.1: Expected Poverty & 63.4 & 84.6 & 84.9 & 68.3 & 67.3 & 66.3 \\
\hline SIM.2: Expected Poverty & 61.5 & 81.9 & 84.3 & 66.8 & 65.5 & 64.7 \\
\hline SIM.3: Expected Poverty & 72.1 & 93.5 & 98.8 & 70.2 & 72.4 & 69.9 \\
\hline \multicolumn{7}{|c|}{ Non-Vulnerable Rural Households } \\
\hline Observed Poverty & 46.5 & 33.6 & 31.8 & 42.8 & 47.1 & 45.3 \\
\hline SIM.1: Expected Poverty & 44.3 & 33.1 & 30.8 & 41.2 & 45.7 & 43.4 \\
\hline SIM.2: Expected Poverty & 43.9 & 32.1 & 30.1 & 40.7 & 44.3 & 42.8 \\
\hline SIM.3: Expected Poverty & 51.6 & 40.9 & 40.4 & 47.4 & 55.2 & 51.7 \\
\hline \multicolumn{7}{|c|}{ Vulnerable Urban Households } \\
\hline Observed Poverty & 68.4 & 71.0 & 71.2 & 67.9 & 45.5 & 55.3 \\
\hline SIM.1: Expected Poverty & 76.4 & 87.7 & 81.1 & 74.1 & 50.7 & 59.9 \\
\hline SIM.2: Expected Poverty & 73.5 & 85.2 & 80.4 & 72.8 & 50.8 & 58.5 \\
\hline SIM.3: Expected Poverty & 83.4 & 92.2 & 92.7 & 80.1 & 58.5 & 66.3 \\
\hline \multicolumn{7}{|c|}{ Non-Vulnerable Urban Households } \\
\hline Observed Poverty & 31.6 & 29.0 & 28.9 & 32.2 & 54.5 & 44.7 \\
\hline SIM.1: Expected Poverty & 29.8 & 27.8 & 28.5 & 31.2 & 54.1 & 42.5 \\
\hline SIM.2: Expected Poverty & 28.6 & 27.2 & 28.3 & 30.7 & 52.9 & 41.8 \\
\hline SIM.3: Expected Poverty & 35.2 & 33.2 & 34.7 & 36.7 & 62.5 & 50.6 \\
\hline
\end{tabular}

Source: Computed from GAMS result 2015

\section{Impact of Wheat and Fish Trade Restriction on Households' Vulnerability to poverty (expressed as a} ratio of expected to observed poverty)

Consequent upon the outcome shown in table 5, the study went further to generate ratio of expected to observed poverty (Table 6). The result indicates the likelihood of more households sinking deep into future poverty particularly the vulnerable rural and urban households. The worst scenario was the combined tariff increase for wheat and fish where there were more households with higher probability of being poor in future. The table also revealed that vulnerable households in the rural zones were the most affected by the combined tariff increase. This is particularly surprising because rural households are expected to be able to cushion the negative effects of higher commodity prices by consuming part or most of their produce while urban households freely abide with the general increase in commodity prices when tariff is increased. Of all the households categories examined, only the households in northeast and northwest experienced higher probabilities of more households sinking into future poverty across rural and urban sectors. 
Table 6: Impact of Wheat and Fish Trade Restriction on Households' Vulnerability to poverty (expressed as a ratio of expected to observed poverty)

\begin{tabular}{|c|c|c|c|c|c|c|}
\hline & N-Central & N-East & N-West & S-East & S-South & S-West \\
\hline \multicolumn{7}{|l|}{ Vulnerable Rural Households } \\
\hline SIM.1: $80 \%$ increase in wheat tariff & 1.19 & 1.27 & 1.24 & 1.19 & 1.27 & 1.21 \\
\hline SIM.2: $50 \%$ increase in fish tariff & 1.15 & 1.23 & 1.24 & 1.17 & 1.24 & 1.18 \\
\hline $\begin{array}{l}\text { SIM.3: } 80 \% \text { \& } 50 \% \text { increase in } \\
\text { wheat \& fish tariff }\end{array}$ & 1.35 & 1.41 & 1.45 & 1.23 & 1.37 & 1.28 \\
\hline \multicolumn{7}{|l|}{ Non-Vulnerable Rural Households } \\
\hline SIM.1: $80 \%$ increase in wheat tariff & 0.95 & 0.98 & 0.97 & 0.96 & 0.97 & 0.96 \\
\hline SIM.2: $50 \%$ increase in fish tariff & 0.94 & 0.95 & 0.95 & 0.95 & 0.94 & 0.94 \\
\hline $\begin{array}{l}\text { SIM.3: } 80 \% \text { \& } 50 \% \text { increase in } \\
\text { wheat \& fish tariff }\end{array}$ & 1.11 & 1.22 & 1.27 & 1.11 & 1.17 & 1.14 \\
\hline \multicolumn{7}{|l|}{ Vulnerable Urban Households } \\
\hline SIM.1: $80 \%$ increase in wheat tariff & 1.12 & 1.23 & 1.14 & 1.09 & 1.11 & 1.08 \\
\hline SIM.2: $50 \%$ increase in fish tariff & 1.08 & 1.20 & 1.13 & 1.07 & 1.12 & 1.06 \\
\hline $\begin{array}{l}\text { SIM.3: } 80 \% \text { \& } 50 \% \text { increase in } \\
\text { wheat \& fish tariff }\end{array}$ & 1.22 & 1.30 & 1.30 & 1.18 & 1.29 & 1.20 \\
\hline \multicolumn{7}{|c|}{ Non-Vulnerable Urban Households } \\
\hline SIM.1: $80 \%$ increase in wheat tariff & 0.94 & 0.96 & 0.99 & 0.97 & 0.99 & 0.95 \\
\hline SIM.2: $50 \%$ increase in fish tariff & 0.90 & 0.94 & 0.98 & 0.95 & 0.97 & 0.94 \\
\hline $\begin{array}{l}\text { SIM.3: } 80 \% \text { \& } 50 \% \text { increase in } \\
\text { wheat \& fish tariff }\end{array}$ & 1.11 & 1.15 & 1.20 & 1.14 & 1.15 & 1.13 \\
\hline
\end{tabular}

Source: Computed from GAMS result 2015

\section{Comparing the Ratios of Expected Poverty to Observed Poverty for the Baseline with the Three Simulated Scenarios}

In Table 7, the ratio of predicted to observed poverty prior to policy simulations was compared with the ratio obtained after each of the three experiments. The result shows the expected number of households (out of every hundred household) that are likely to move out of poverty or sink deeper into poverty. Progressively across the household categories the ratio of predicted to observed poverty increased leading to possibility of more households getting worse than they were prior to policy shocks. The scenario of combined shock gave the highest ratios across rural, urban, vulnerable and non-vulnerable households. A particular point of interest and concern was the likely switch of households that were hitherto in the categories of non-vulnerable which were now vulnerable. Even in simulations 1 and 2 where non-vulnerable households still maintain the status quo, their expected poverty rose significantly when compared with the expected poverty that was computed for the baseline. This is an indication that food import restriction policies do not favour households' welfare in Nigeria. However, if the combine effects of increase in labour and income, employment generation, greater food production at the domestic level and reduction in food import bills are factored in as benefits accrued from trade restriction policy, perhaps households' strength to cope with better consumption may be renewed in the future as envisaged in the cardinal objectives of Agricultural Transformation Agenda (2011-2016) and Agricultural Promotion Policy (2016). 
Table 7: Comparing the Ratios of Expected Poverty to Observed Poverty for the Baseline with the Three Simulated Scenarios

\begin{tabular}{|c|c|c|c|c|}
\hline & $\begin{array}{l}\text { Ratio of Expected } \\
\text { to Observed poverty } \\
\text { before the Shocks }\end{array}$ & $\begin{array}{l}\text { Ratio of Expected } \\
\text { to Observed poverty } \\
\text { after } 80 \% \text { wheat } \\
\text { Shock }\end{array}$ & $\begin{array}{l}\text { Ratio of Expected } \\
\text { to Observed poverty } \\
\text { after } 50 \% \text { fish } \\
\text { Shock }\end{array}$ & $\begin{array}{l}\text { Ratio of Expected } \\
\text { to Observed poverty } \\
\text { after the Combined } \\
\text { Shock }\end{array}$ \\
\hline \multicolumn{5}{|c|}{ Vulnerable Rural Households } \\
\hline North Central & 1.25 & 1.19 & 1.15 & 1.35 \\
\hline North East & 1.22 & 1.27 & 1.23 & 1.41 \\
\hline North West & 1.23 & 1.24 & 1.24 & 1.45 \\
\hline South East & 1.16 & 1.19 & 1.17 & 1.23 \\
\hline South South & 1.23 & 1.27 & 1.24 & 1.37 \\
\hline South West & 1.13 & 1.21 & 1.18 & 1.28 \\
\hline \multicolumn{5}{|c|}{ Non-Vulnerable Rural Households } \\
\hline North Central & 0.71 & 0.95 & 0.94 & 1.11 \\
\hline North East & 0.86 & 0.98 & 0.95 & 1.22 \\
\hline North West & 0.85 & 0.97 & 0.95 & 1.27 \\
\hline South East & 0.79 & 0.96 & 0.95 & 1.11 \\
\hline South South & 0.74 & 0.97 & 0.94 & 1.17 \\
\hline South West & 0.82 & 0.96 & 0.94 & 1.14 \\
\hline \multicolumn{5}{|c|}{ Vulnerable Urban Households } \\
\hline North Central & 1.07 & 1.12 & 1.08 & 1.22 \\
\hline North East & 1.06 & 1.23 & 1.20 & 1.30 \\
\hline North West & 1.08 & 1.14 & 1.13 & 1.30 \\
\hline South East & 1.05 & 1.09 & 1.07 & 1.18 \\
\hline South South & 1.10 & 1.11 & 1.12 & 1.29 \\
\hline South West & 1.06 & 1.08 & 1.06 & 1.20 \\
\hline \multicolumn{5}{|c|}{ Non-Vulnerable Urban Households } \\
\hline North Central & 0.82 & 0.94 & 0.90 & 1.11 \\
\hline North East & 0.81 & 0.96 & 0.94 & 1.15 \\
\hline North West & 0.84 & 0.99 & 0.98 & 1.20 \\
\hline South East & 0.78 & 0.97 & 0.95 & 1.14 \\
\hline South South & 0.87 & 0.99 & 0.97 & 1.15 \\
\hline South West & 0.76 & 0.95 & 0.94 & 1.13 \\
\hline
\end{tabular}

Source: Computed by the authors

\section{Conclusion}

The following conclusions were drawn from the empirical results that emanated from the study. This study evaluated the impacts of agricultural trade tariff policy measures for wheat and fish on output, value added, gross fixed capital formation (GFCF), and household consumption expenditure performance in Nigeria within a static CGE framework. The efficacy of various increases in tariffs at boosting output, value added and labour and capital employment in all the economic sectors were analysed. The results of the simulation exercises suggest that agricultural sector would benefit immensely from import tax increases that would sufficiently reduce wheat and fish imports, give opportunities for expansion in the sector's output with value added.

\section{Policy Recommendations}

From the policy point of view, the severe pressures on the nation's external reserves, foreign indebtedness and balance of payments position brought about by the introduction of gradual trade liberalization policy should be reconsidered. Therefore, the agricultural trade restrictive policy would insulate the domestic food production from foreign competition and encourage the growth of import based agricultural crop substitutes. The results of the scenario analyses show that a tariff policy needs to be carefully designed in order to achieve its set objectives. This is because a particular agricultural trade restriction policy on wheat and fish that is meant to promote import substitutes in terms of wheat and fish production for the domestic economy may end up worsening the situation in the same sector if the technology that can promote value addition is not promoted alongside

In particular, agricultural trade restriction policy should take into consideration the Nigeria's comparative advantage. Even if Nigeria's wheat production cannot match the demand for wheat based products, production of substitute crops that can be combined with wheat flour could be encouraged. This is the policy statement of the ATA for wheat and fish production and their substitutes such as the high quality cassava flour of the IITA and 
some fish species that are being largely produced domestically. For Nigeria to build on its potentials to produce wheat and fish that are of high relative importance in household consumption, relevant sectors have to be protected.

Once policy makers set a target, it should be maintained. Therefore for the objectives of the Agricultural Transformation Policy to be achieved, the agricultural sector must continue to be protected, especially in a country like Nigeria where the sector is largely rural based. The policy implications of this study were that there was a remarkable improvement in the employment of labour and capital (value added) for wheat and fish in all the scenarios experimented. This means that restrictive policies promoted production of close substitutes for import commodities. Thus, resource movement was between agricultural imports and domestic local food production. This has positive implication for foreign exchange in terms of huge annual food import bills and food self sufficiency of the country. Therefore, policy thrust must be such that ensure improvement in the use of domestic resources for food production. For now in Nigeria, restrictive policy regime is more beneficial to the agricultural sector and the economy as a whole when compared with what obtain during the liberalized policy regime.

\section{References}

Adepoju A. O. and S. A. Yusuf 2011. Poverty and Vulnerability in Rural South-West Nigeria. ARPN Journal of Agricultural and Biological Science Vol 7, No. 6, pg. 430-437.

Bhasin V. K. 2008. Agricultural Trade Liberalization Financing and its Impact on Poverty in Ghana. African Journal of Economic Policy, Vol. 15, No. 1.Pgs 107- 138.

Chaudhuri, S. 2002. Empirical Methods for Assessing Household Vulnerability to Poverty. Mimeo, New York: Department of Economics, Columbia University.

Chipman, J.S. 1987. "Bickerdike's Theory of Incipient and Optimal Tariffs," unpublished paper.

Christiaensen, L., and K. Subbarao 2005. "Towards an Understanding of Vulnerability in Rural Kenya." Journal of African Economies, Vol.14 No.4

CIMMYT (International Maize and Wheat Improvement Centre), 2000. "Wheat production fact and trends. Global wheat research in a changing world: challenges and achievements". (CIMMYT), Mexico.

Cockburn, John. 2001. "Trade Liberalization and Poverty in Nepal: A Computable General Equilibrium Micro Simulation Analysis," CREFA working paper (01-18).

Decaluwe, B., A. Lemelin, V. Robichaud, H. Maisonnave 2013. PEP-1-1.The PEP standard single-country, static CGE model (2.1), Poverty and Economic Policy Research Network, Universite' Laval, Quebec. http://www.pep-net.org/programs/mpia/pep-standard-cge-models/.

Emran, S. and J. Stiglitz 2005. "On Selective Indirect Tax Reform in Developing Countries" Journal of Public Economics Vol. 89, pgs.599-623

Fadare, S. 2014. "N 9.9 billion fund: still a long walk to cassava bread". The Nations Newspaper 2 July 2014.

FMARD, 2014. "Agricultural Transformation Agenda: revives hope for national food security". Federal Ministry of Agricultural and Rural Development (FMARD), Abuja

Kearl et, al. 1979. "A Confusion of Economics" The American Economic Review. Papers and Proceedings of the Ninety-First Annual Meeting of the American Economic Association Vol. 69, No. 2, pgs. 28-37

Miller, et al 2007. 'Integrated Irrigation-Aquaculture Opportunities in Nigeria' in I ntegrated Irrigation and Aquaculture in West Africa: Concepts, Practces and Potential, Halwart, M. et al (Eds), FAO

Minor P. and B. Mureverwi 2013. A Household Level Analysis of African Trade Liberalization: The case of Mozambique World Bank, BNPP program April 2013.

Nkang, N. M., B. T. Omonona, S. A. Yusuf, O. A. Oni, 2013. Simulating the Impact of Exogenous Food Price Shock on Agriculture and the Poor in Nigeria: Results from a Computable General Equilibrium Model. Journal of the Economic Society of Australia (Queensland) Vol. 43 No. 1 pgs $79-94$

Novignon J., J. Novignon, R. Mussa, and L. S. Chiwuala 2012. Health and vulnerability to

poverty in Ghana: evidence from the Ghana Living Standards Survey Round 5. Journal of Economic Review Volume 2 (11)

Obi-Egbedi O.; V. O. Okoruwa; S. A. Yusuf; K. O. Adenegan; and A. Aminu 2013. Rice Trade Protectionism versus Liberalization in Nigeria: A CGE Analysis of Economic and Welfare Effects. Paper presented at the 4th International Conference of the African Association of Agricultural Economists, September 22-25, 2013, Hammamet, Tunisia

Ohimain E.I., 2014. "The Prospects and Challenges of Composite Flour for Bread Production in Nigeria". Global Journal of Human - Social Science, vol. 14, no. 3, pp. 49-52.

Oni, A. O. and S. A. Yusuf 2008. Determinants of Expected Poverty among Rural Households in Nigeria. Final Report presented at the AERC Biannual Workshop in Nairobi, Kenya, December.

Pritchett, L., A. Suryahadi, and S. Sumarto 2000. Quantifying vulnerability to poverty: A proposed measure, with application to Indonesia. SMERU Working Paper 
Rousslang, D. 1987. “The Opportunity Cost of Import Tariffs.” Kyklos, Vol. 40, 1987.

Sustainable Aquaculture Digital News 2014. Nigeria Begins Import Quota for Fish. The Fish Site News Desk Benchmark House, 8 Smithy Wood Drive, Sheffield, S35 1QN, England

Torrens, R. 1844. Letter II of The Budget. On Commercial and Colonial Policy.(London: Smith, Elder and Co., No. 65,Cornhill,), p. 37.

Yusuf, S. A. 2002. A Computable General Equilibrium Analysis of Poverty among Socio economic Groups in Nigeria. Issues in African Rural Development Monograph Series No. 13 August, African Rural Policy Analysis Network (ARPAN), Winrock International 